УДК: 636.92.591.133.16

\title{
RESISTANCE OF THE RABBIT DAMS' ORGANISM AT DRINKING SUPPLEMUTED BY CHLORELLA SUSPENSION, SODIUM SULFATE, CHROMIUM CHLORIDE AND CITRATE
}

\author{
Ya. V. Lesyk \\ yaroslav_lesyk@inenbiol.com.ua
}

Institute of Animal Biology NAAS, Lviv 79034, 38 Stus st., Ukraine

The aim at resealed was to study the influence of Chlorella suspension, sodium sulfate, chromium chloride and citrate on the physiological blood indices and nonspecific resistance of female rabbits during the period from copulation to the lactation peak. The number of erythrocytes, hemoglobin concentration, the aminotransferases activity, phagocytic activity of neutrophils, lysozyme and bactericidal activity of rabbit dams', blood serum at introduction of Chlorella suspension, sodium sulfate, citrate and chromium chloride into the ration were determined. Researches were conducted on silver breed rabbits'females, 110-114 days age, weighing 3.7$3.9 \mathrm{~kg}$ divided into five groups (one control and four experimental) 12 females each, selected on the basis of analogues principle. Control group rabbits were fed enough balanced granulated mixed fodder with free access to water. The 1st experimental group, except for mixed fodder, starting from the first research day received 90$110 \mathrm{ml}$ of Chlorella suspension with water. The second experimental group's animals were fed mixed fodder similarly to I experimental group's schemes and drink, except for Chlorella, sodium sulfate in an amount of $40.0 \mathrm{mg} / \mathrm{kg}$ body weight or 0.15-0.17 g $S$ per day. Females of the third experimental group received mixed fodder and water according to II group's scheme with extra drinking Chromium as $\mathrm{CrCl}_{3} \times 6 \mathrm{H}_{2} \mathrm{O}$, in the amount of 28-32 $\mathrm{mg} \mathrm{Cr}$ per day at the rate of 7.6 $\mathrm{mg} / \mathrm{kg}$ of body weight. Animals of the fourth experimental group received mixed fodder and water according to the II group's schemes with additional introduction into the water of Chromium citrate obtained by using nanotechnology at the rate of $2.2 \mathrm{mg} \mathrm{Cr} / \mathrm{kg}$ body weight or 8-12 mg Cr per day. Researched established that in the blood of II, III and IV research groups' rabbits that additionally consumed sodium sulphate, chloride and chromium citrate, the number of erythrocytes, hemoglobin and total protein concentration, and activity of alanine aminotransferase were credibly higher on the 67 day of the study compared to the control group. Introduction to the diet of II, III and IV groups' rabbits of mineral supplementation resulted in high immunological reactivity of organism with the increase of phagocytic activity of neutrophils, lysozyme and bactericidal activity level in the blood compared with animals of the control group.

Keywords: RABBITS, CHROMIUM, PHYSIOLOGICAL BLOOD PARAMETERS, NONSPECIFIC RESISTANCE

\section{РЕЗИСТЕНТНІСТЬ ОРГАНІЗМУ КРОЛЕМАТОК ЗА ВИПОЮВАННЯ СУСПЕНЗІЇ ХЛОРЕЛИ, СУЛЬФАТУ НАТРІЮ, ХЛОРИДУ І ЦИТРАТУ ХРОМУ}

\author{
Я. В. Лесик \\ yaroslav_lesyk@inenbiol.com.ua
}

Інститут біології тварин НААН, Україна, Львів 79034, вул. В. Стуса, 38

\begin{abstract}
Метою дослідження було вивчити вплив суспензї хлорели, сульфату натрію, хлориду $i$ ичитрату хрому на фізіологічні показники крові та неспецифічну
\end{abstract}

\author{
резистентність організму самок кролів у \\ період від парування до піку лактації. \\ Визначили кількість еритрочуитів, \\ концентрацію гемоглобіну, активність
}


амінотрансфераз, фагочитарну активність нейтрофілів, фагоцитарний індекс, фагоцитарне число, лізощимну $і$ бактерицидну активність сироватки у крові кролематок за введення до раціону суспензії хлорели, сульфату натрію, иитрату і хлориду хрому. Дослідження проводили на самках кролів, віком 110-114 діб, масою тіла 3,7-3,9 кг породи сріблястий, поділених на п'ять груп (контрольну $і$ чотири дослідні), по 12 самок у кожній, підібраних за принципом аналогів. Кроличям контрольної групи згодовували вволю збалансований гранульований комбікорм з вільним доступом до води. Самки I дослідної групи, крім комбікорму, $з$ першого дня дослідження 3 водою отримували 90-110 мл суспензії хлорели. Тваринам II дослідної групи, аналогічно зі схемою I дослідної групи, згодовували комбікорм, а з водою, крім хлорели, випоювали сульфат натрію в кількості 40,0 мг/кг маси тіла або 0,15-0,17 г S/mварину/добу. Самиці III дослідної групи отримували комбікорм і воду за схемою II групи з додатковим випоюванням 3 водою Хрому у виглядi $\mathrm{CrCl}_{3} \quad x \quad 6 \mathrm{H}_{2} \mathrm{O}, \quad$ в кількості 28-32 мкг Сr/mварину/добу 3 розрахунку 7,6 мкг/кг маси тіла. Тварини IV дослідної групи отримували комбікорм $i$ воду відповідно до схеми II групи з додатковим введенням у воду иитрату хрому, отриманого методом з використанням нанотехнології, $з$ розрахунку 2,2 мкг Сr/кг маси тіла або 8-12 мкг Сr/тварину/добу. Встановлено, що у крові кролиць II, III і IV дослідних груп, які додатково споживали в рачіоні сульфат натрію, хлорид $i$ цитрат хрому, кількість еритрочичтів, концентрація гемоглобіну $i$ загального білка та активність АлАТ були вірогідно вищими на 67 добу дослідження порівняно з контрольною групою. Уведення до раціону кролів II, III $i$ IV груп мінеральних добавок зумовлювало високу імунобіологічну реактивність їхнього організму з підвищенням у крові рівня фагоџитарної активності нейтрофілів, лізочимної $i$ бактерииидної активності, порівняно з тваринами контрольної групи.

Ключові слова: КРОЛІ, ХРОМ, ФІЗІОЛОГІЧНІ ПОКАЗНИКИ КРОВІ, НЕСПЕЦИФІЧНА РЕЗИСТЕНТНІСТЬ ОРГАНІЗМУ

\title{
РЕЗИСТЕНТНОСТЬ ОРГАНИЗМА КРОЛЬЧИХ ПРИ ВЫПАИВАНИИ СУСПЕНЗИИ ХЛОРЕЛЛЫ, СУЛЬФАТА НАТРИЯ, ХЛОРИДА И ЦИТРАТА ХРОМА
}

\author{
Я. В. Лесик \\ yaroslav_lesyk@inenbiol.com.ua
}

\section{Институт биологии животных НААН, Украина, Львов 79034, ул. В. Стуса, 38}

Целью исследования было изучить влияние суспензии хлорелль, сульфата натрия, хлорида и ичттрата хрома на физиологические показатели крови и неспецифическую резистентность крольчих в период от спаривания до пика лактаџии. Исследовали количество эритроцчитов, концентрациию гемоглобина, активность аминотрансфераз, фагоциитарную активность нейтрофилов, лизочимную и бактерицидную активность сыворотки в крови крольчих при введении в рацион суспензии хлорелль, сульфата натрия, циттрата и хлорида хрома. Исследования проведены на самках кроликов в возрасте 110 114 суток, массой тела 3,7-3,9 кг породы серебристый разделенных на пять групп (контрольную и четыре опьтные), по 12 самок в каждой, подобранных по принциипу аналогов. Крольчихам контрольной группь скармливали без ограничения сбалансированный гранулированный комбикорм и воду. Самки I опьтной группь, кроме комбикорма с первого дня исследования с водой получали 90-110 мл суспензии хлорелль. Животным II опытной группь, аналогично схеме I группь, скармливали комбикорм, а с водой кроме хлорелль выпаивали сульфат натрия в количестве 40,0 мг/кг массы тела или 0,15-0,17 2 S/животное/сутки. Самки III опьтной группь получали комбикорм и воду по схеме II группь с дополнительной выпойкой хрома в виде $\mathrm{CrCl}_{3} \times \mathrm{CH}_{2} \mathrm{O}$, в количестве 28-32 мкг Сr/животное/сутки из расчета 7,6 мкг/кг массы тела. Животные IV опытной группь получали комбикорм и воду согласно схеме II-й группь с дополнительньм введением в воду циттрата хрома, полученного методом $c$ использованием нанотехнологии из расчета 
2,2 мкг Сr/кг массы тела или 8-12 мкг Сr/жнвотное/сутки. Исследованиями установлено, что в крови кроликов II, III и IV опытнных групп, которые дополнительно потребляли в рационе сульфат натрия, хлорид и циттрат хрома, количество эритрочитов, концентрация гемоглобина, общеео белка и активность АлАТ были достоверно выше на 67 сутки опыта по сравнению с контрольной группой. Введение в рациио кроликов II, III и IV групп минеральных добавок привело к высокой иммунобиологической реактивности их организма с повышением в крови уровня фагоцитарной активности нейтрофилов, лизочиимной и бактерицидной активности по сравнению с животными контрольной группь.

\begin{tabular}{|c|c|}
\hline Ключевые & КРОЛИКИ, \\
\hline XPOM, & ФИЗИОЛОГИЧЕСКИ \\
\hline ПОКАЗАТЕЛИ & KP \\
\hline НЕСПЕЦИФИЧЕС & $A Я$ \\
\hline РЕЗИСТЕНТНОС & ОРГАНИЗМА \\
\hline
\end{tabular}

At intensive rabbit breeding in industrial environment where females are under stress and influence of adverse environmental factors, considerable attention is paid to increasing female rabbits' resistance $[1,2]$. Resistance of animals mainly depends on the development and functioning of the immune system and a number of environmental factors, including: maintenance conditions and balanced nutrition, especially for mineral elements, amino acids and vitamins [3].

Intensive industrial technologies of rabbits' breeding cause periodic stress conditions, particularly in females, consequently disturbing organism's homeostasis, which contributes to inhibition of natural resistance, reducing the productive qualities of animals, immunodeficiency development, as a result organism is unable to produce the necessary amounts of antibodies to resist diseases $[4,5,6]$. Considerable researchers' attention is paid to studying the relationship between immune defense of the organism and its supply by minerals involved in the distribution and reproduction of cells, regulation of amino acids, proteins and nucleotides metabolism [7, 8]. The main problem in the organization of biologically valuable rabbits' feeding under these conditions, is to find additional natural vitamin and mineral fodder additives that allow to improve nutrient absorption of the offered rations in Ukraine, which don't always satisfy the nutrient needs of young fast-growing, pregnant and lactating females [9].

Recent studies show that chromium and sulfur are vital for normal proteins, carbohydrates and fats metabolism in animals' and are minerals that affect the immune system functional activity $[10,11]$. It is known that chromium in animal tissues supplements, especially at critical physiological periods [12]. This condition is caused by low Chromium assimilation from the fodder, which can lead to metabolic disorders. Stress factors that stimulate trivalent chromium release affect its absorption in animals' organism. Technological stresses always act in industrial livestock causing the deficit of $\mathrm{Cr}$ (III) in animals. Chromium enhances the effects of insulin, and influences the regulation of metabolism in general. Increase of insulin influence occurs without changing the amount of the hormone, while it's entirely dependent on the chromium content [13].

Organism's reproductive function is controlled and regulated by complex multilevel neuro humoral and functional systems with direct positive and negative reverse connections. In its turn, changes in immune status may cause changes in reproductive function of female rabbits. Therefore the purpose of our study was to examine the effect of Chlorella suspension, sodium sulfate, chromium chloride and citrate on physiological parameters of blood and nonspecific resistance of female rabbits during the period of breeding and to the peak of lactation.

\section{Materials and Methods}

Researches were conducted on silver breed rabbits' females, 110-114 days age, weighing $3.7-3.9 \mathrm{~kg}$ on the rabbit farm in villlage Novosilky Busk district, Lviv region, divided into five groups (control and four experimental) 12 females each, selected on the 
basis of analogues principle. Female rabbits of the control group were fed enough balanced granular mixed fodder [14] with free access to water. Females of the I experimental group except for mixed fodder received with water a suspension of chlorella strain - Chlorella vulgaris BIN from the first day of the study in the ratio (1:3) at the rate of $90-110 \mathrm{ml}$ per day. Animals of the second experimental group, were fed similarly to I group animals with additional drinking except for Chlorella of sodium sulfate in an amount of $40.0 \mathrm{mg} / \mathrm{kg}$ body weight or $0.15-0.17 \mathrm{~g} \mathrm{~S}$ per day. Females of third experimental group received fodder and water according to group II scheme in with extra drinking of Chromium as $\mathrm{CrCl}_{3} \mathrm{x}$ $6 \mathrm{H}_{2} \mathrm{O}$, in the amount of 28-32 mg Cr per day at the rate of $7.6 \mathrm{mg} / \mathrm{kg}$ of body weight. Animals of fourth experimental group received fodder and water according to II group's scheme with additional introduction in water of chromium citrate obtained by Kosinov M. V., Kaplunenko V. G. method using nanotechnology [15] at the rate of 2.2 $\mathrm{mg} \mathrm{Cr} / \mathrm{kg}$ body weight or $8-12 \mathrm{mg} \mathrm{Cr}$ per day. Animals were kept in single-tier mesh cages in buildings with controlled microclimate, according to current veterinary and sanitary standards. Duration of study was 77 days, including accommodation period - 10 days and period experiment - 67 days. In the accommodation period on 105 day of life (10 days before coupling to copulation) and period experiment - on 172 day of life (20-22 day of lactation), blood samples were taken from the marginal ear vein of rabbit females for biochemical studies - erythrocytes concentration of hemoglobin, total protein, aminotransferase activity, phagocytic activity of neutrophils (FAN), phagocytic index (FI), phagocytic number (FN) lysozyme activity (LA), serum bactericidal activity (SBA) was determined in blood described in [16]. Digital data were processed statistically using Student's t criteria.

\section{Results and discussion}

It should it was revealed be noted that the inclusion of strain Chlorella vulgaris BIN suspensions into the diet of females of I experimental group during the accommodation period, didn't have significant effect on physiological parameters of blood (tabl. 1). However, drinking II group rabbits during the experimental period, of supplements that included a suspension of Chlorella and sodium sulfate, was accompanied by an increase of erythrocytes level by $16.0 \% \quad(p<0.05)$, hemoglobin $-4.0 \%(\mathrm{p}<0.05)$, and ALT by $9.0 \%(p<0.05)$ compared with the control group. Obviously, stimulating effect on the hematopoiesis state was caused by high biological action of sodium sulphate, which positively influenced the respiratory function enhancement, improvement of oxygen supply and an increase in the intensity of oxidationreduction processes in the dams' organism.

Organism's resistance is caused by specific and nonspecific immune mechanisms condition associated with metabolic processes features in lactating dams that change under the influence of vitamins and minerals. The most significant differences of the studied blood parameters between the control and experimental groups were marked at application of dietary chromium compounds in combination with a suspension of Chlorella and sodium sulfate. In particular, in the blood of III and IV research groups rabbits the number of erythrocytes, hemoglobin concentration and ALT activity was significantly higher on the 67 day of drinking supplements compared with the control group. These differences may indicate the increasing of lactating females organism's resistance under the influence of both chloride and chromium citrate. This effected positively the insulin secretion and improved the ability of the hormone's binding capability with cells receptors by peptide chromium moduline, which includes chromium and caused the activation of metabolic processes, as well as hematopoietic and immune system of the organism. 
Physiological blood parameters of female rabbits $(M \pm m, n=5)$

\begin{tabular}{|c|c|c|c|}
\hline \multirow{2}{*}{ Indicators } & \multirow{2}{*}{ Group } & \multicolumn{2}{|c|}{ Period of research, day of life } \\
\hline & & preparatory, 105 & research, 172 \\
\hline \multirow{5}{*}{$\begin{array}{c}\text { Erythrocytes, } \\
\text { T/1 }\end{array}$} & $\mathrm{C}$ & $4.66 \pm 0.10$ & $4.57 \pm 0.28$ \\
\hline & E-I & $4.68 \pm 0.10$ & $4.65 \pm 0.17$ \\
\hline & E-II & $4.91 \pm 0.73$ & $5.28 \pm 0.19 *$ \\
\hline & E-III & $4.80 \pm 0.91$ & $5.33 \pm 0.23 *$ \\
\hline & E-IV & $4.97 \pm 0.99$ & $5.76 \pm 0.19^{* *}$ \\
\hline \multirow{5}{*}{$\begin{array}{l}\text { Hemoglobin, } \\
\mathrm{g} / 1\end{array}$} & $\mathrm{C}$ & $108.5 \pm 0.70$ & $124.9 \pm 1.10$ \\
\hline & E-I & $107.2 \pm 1.71$ & $124.2 \pm 1.06$ \\
\hline & E-II & $107.3 \pm 1.89$ & $128.8 \pm 0.97 *$ \\
\hline & E-III & $108.5 \pm 1.58$ & $129.7 \pm 2.20 *$ \\
\hline & E-IV & $109.6 \pm 1.57$ & $130.3 \pm 2.32 *$ \\
\hline \multirow{5}{*}{ Total protein, g/l } & $\mathrm{C}$ & $64.7 \pm 0.64$ & $60.5 \pm 0.40$ \\
\hline & E-I & $65.8 \pm 0.91$ & $61.3 \pm 1.05$ \\
\hline & E-II & $64.8 \pm 1.07$ & $61.6 \pm 0.56$ \\
\hline & E-III & $66.1 \pm 1.09$ & $62.3 \pm 0.81^{*}$ \\
\hline & E-IV & $66.0 \pm 0.97$ & $63.1 \pm 0.54^{*}$ \\
\hline \multirow{5}{*}{$\begin{array}{c}\text { ALT, } \\
\text { mkkat / } 1\end{array}$} & $\mathrm{C}$ & $0.327 \pm 0.08$ & $0.334 \pm 0.01$ \\
\hline & E-I & $0.335 \pm 0.08$ & $0.346 \pm 0.01$ \\
\hline & E-II & $0.340 \pm 0.03$ & $0.365 \pm 0.01 *$ \\
\hline & E-III & $0.349 \pm 0.06$ & $0.384 \pm 0.02 *$ \\
\hline & E-IV & $0.365 \pm 0.01$ & $0.372 \pm 0.01 *$ \\
\hline \multirow{5}{*}{$\begin{array}{l}\text { AST, } \\
\text { mkkat / } 1\end{array}$} & $\mathrm{C}$ & $0.221 \pm 0.09$ & $0.201 \pm 0.03$ \\
\hline & E-I & $0.219 \pm 0.09$ & $0.206 \pm 0.01$ \\
\hline & E-II & $0.208 \pm 0.01$ & $0.220 \pm 0.01$ \\
\hline & E-III & $0.237 \pm 0.01$ & $0.225 \pm 0.01$ \\
\hline & E-IV & $0.220 \pm 0.01$ & $0.212 \pm 0.01$ \\
\hline
\end{tabular}

Note. In this and the following tables statistically significant differences are given in accommodation to the animals of the control group: * $-\mathrm{p}<0.05, * *-\mathrm{p}<0.01, * * *-\mathrm{p}<0.001$

Using supplements that differed by presence of sodium sulfate, chromium chloride and citrate in the diet of female rabbits was marked by significantly higher rates of phagocytic immunity link's levels of their blood compared with control group (tabl. 2). Thus, on 67 day of study phagocytic activity of neutrophils in the blood of II, III and IV experimental groups rabbits was higher by 7.0, 9.0 and $14.0 \%(\mathrm{p}<0.05)$ compared with the control group. The study of phagocytosis intensity by phagocytic index and phagocytic number indicates that their values correlated with the index of phagocytic activity of neutrophils in rabbits of the experimental groups and their changes were minor compared with the control.

Humoral defense link activity of animals is a regulatory factor for the process of phagocytosis, since they show a stimulating effect on the phagocytic response and activate immune-competent cells [10]. To determine humoral factors of nonspecific organism's defense in female rabbits we studied lysozyme activity of blood serum on 105 and 172 days of life. It was established that drinking supplements during 67 days contributed to probable increase of lysozyme activity in animals' blood of II, III and IV experimental groups respectively by $10.0,19.0$ and $29.0 \%$ compared with the control group. These results may indicate a positive effect of applied additions in the diet of rabbits on the immunological capacity of their organism.

Bactericidal activity of serum is the integral indicator of the of the organism's natural resistance, which is caused by the presence of components that neutralize microbial cells in blood. High bactericidal activity of serum is associated with the lysozyme content that possesses cytolytic properties concerning microorganisms. It is able, on the one hand, to break down the relationship between $\mathrm{N}$-acetylmuramic acid and $\mathrm{N}$-acetylglucosamine as an enzyme, and on the other hand, lysozyme is able to mobilize other nonspecific factors of organism's defense. 
Indicators of nonspecific resistance of female rabbits' organism $(M \pm m, n=4)$

\begin{tabular}{|c|c|c|c|}
\hline \multirow{2}{*}{ Indicators } & \multirow{2}{*}{ Group } & \multicolumn{2}{|c|}{ Period of research, day of life } \\
\hline & & preparatory, 105 & research, 172 \\
\hline \multirow{5}{*}{$\begin{array}{l}\text { Phagocytic activity of } \\
\text { neutrophils, } \%\end{array}$} & $\mathrm{C}$ & $40.3 \pm 0.88$ & $48.0 \pm 1.15$ \\
\hline & E-I & $41.3 \pm 1.76$ & $49.7 \pm 0.88$ \\
\hline & E-II & $40.0 \pm 0.57$ & $51.0 \pm 1.57 *$ \\
\hline & E-III & $40.0 \pm 0.58$ & $52.3 \pm 1.45^{*}$ \\
\hline & E-IV & $41.0 \pm 1.52$ & $54.3 \pm 0.88^{*}$ \\
\hline \multirow{5}{*}{$\begin{array}{c}\text { Phagocytic index, } \\
\text { units. }\end{array}$} & $\mathrm{C}$ & $8.59 \pm 0.33$ & $7.32 \pm 0.16$ \\
\hline & $\mathrm{E}-\mathrm{I}$ & $8.98 \pm 0.54$ & $7.37 \pm 0.13$ \\
\hline & E-II & $8.79 \pm 0.23$ & $8.46 \pm 0.57$ \\
\hline & E-III & $8.97 \pm 0.31$ & $8.97 \pm 0.46$ \\
\hline & E-IV & $8.06 \pm 0.76$ & $8.23 \pm 0.26$ \\
\hline \multirow{5}{*}{$\begin{array}{l}\text { Phagocytic number } \\
\text { units }\end{array}$} & $\mathrm{C}$ & $3.46 \pm 0.14$ & $4.00 \pm 0.17$ \\
\hline & E-I & $3.73 \pm 0.37$ & $4.13 \pm 0.12$ \\
\hline & E-II & $3.86 \pm 0.33$ & $4.26 \pm 0.21$ \\
\hline & E-III & $3.83 \pm 0.24$ & $4.16 \pm 0.12$ \\
\hline & E-IV & $3.34 \pm 0.20$ & $4.93 \pm 0.14$ \\
\hline \multirow{5}{*}{ Lysozyme activity, \% } & $\mathrm{C}$ & $42.3 \pm 1.45$ & $45.3 \pm 0.87$ \\
\hline & $\mathrm{E}-\mathrm{I}$ & $42.6 \pm 1.85$ & $46.3 \pm 0.88$ \\
\hline & E-II & $43.3 \pm 0.88$ & $49.6 \pm 1.20^{*}$ \\
\hline & E-III & $42.6 \pm 1.45$ & $53.6 \pm 0.88 * *$ \\
\hline & $\mathrm{E}-\mathrm{IV}$ & $40.6 \pm 1.45$ & $58.3 \pm 0.86^{* * *}$ \\
\hline \multirow{5}{*}{$\begin{array}{l}\text { Bactericidal activity of } \\
\text { serum, } \%\end{array}$} & $\mathrm{C}$ & $41.0 \pm 0.89$ & $46.6 \pm 0.89$ \\
\hline & $\mathrm{E}-\mathrm{I}$ & $41.2 \pm 1.49$ & $47.3 \pm 1.37$ \\
\hline & $\mathrm{E}-\mathrm{II}$ & $42.7 \pm 3.34$ & $49.0 \pm 0.86^{* * *}$ \\
\hline & E-III & $42.0 \pm 2.99$ & $51.8 \pm 1.01^{*}$ \\
\hline & E-IV & $42.4 \pm 2.27$ & $54.1 \pm 1.90 * *$ \\
\hline
\end{tabular}

It's present in azurophilic granules and specific neutrophils grains and also monocytes and macrophages grains [17]. Similarly, serum bactericidal activity reacted to the action of above listed fodder the experimental groups in comparison to control. Thus, the blood of II, III and IV groups' animals blood serum bactericidal activity level in the experimental period was higher by $6.0 \%(\mathrm{p}<0.001), 12.0 \%$ $(\mathrm{p}<0.05)$ and $16.0 \%(\mathrm{p}<0.01)$ compared with the control group. These results indicate the increase of the rabbits immunity, especially humoral non-specific defense of the organism at the action of the studied fodder in additives.

\section{Conclusions}

Conducted researches established that drinking female rabbits sulfate, sodium chloride and chromium citrate in specified quantities of 105 to 172-day age was marked by probable changes of physiological blood parameters compared with the control group. In the blood of II, III and IV experimental groups' rabbits fed sodium sulphate and its combination with chloride and chromium citrate, probably higher number of erythrocytes, hemoglobin concentration and total protein and ALT after 67 days additions application was observed compared with the control group. Studies results of the females' organism nonspecific resistance indices show their significantly higher levels in the blood of experimental groups' animals compared with the control group. Introduction of sulfur and chromium compounds into the rabbits' diet resulted in more pronounced immunological reactivity of their organism with increasing concentrations of phagocytosis, and bactericidal activity lysozyme levels compared with animals of the control group.

Enriching diets of rabbits with protein and mineral supplements contribute to effective correction of mineral metabolism in their organism. This will strengthen their adaptation properties, immunological reactivity and positively influence the organism's reproductive function of rabbits' females in industrial environment conditions at intensive rabbit breeding. 
Prospects of further researches. It's advisable to continue researches on the influence of sodium sulfate and chromium compounds in different ratios on the reproductive function of lactating rabbits' females organism.

1. Trocino A., Xiccato G. Animal welfare in reared rabbits: a review with emphasis on housing systems. World Rabbit Sci., 2006, vol. 14, pp. 77-93.

2. Shylov Yu.Y., Shylov S.Yu., Lanyn D.R. Adrenerhycheskye mekhanyzmy rehulyatsyy ymmunnoho otveta y funktsyy nespetsyfycheskykh effektornykh kletok pry stresse [Adrenergic mechanisms regulationof immune response and functions of non-specific effector cells under stress]. Medytsynskaya ymmunolohyya - Medical immunology , 2005, T. 7, no 2-3, S. 127-128 (in Ukrainian).

3. Carabaño R., Badiola I., Chamorro S., García J., García-Ruiz A.I., García-Rebollar P., Gomez-Conde M. S., Gutiérrez I., Nicodemus N., Villamide M. J., de Blas J. C. New trends in rabbit feeding: Influence of nutrition on intestinal health. Spanish J. Agri. Res., 2008, vol. 6, pp.15-25.

4. Maertens L., Štruklec M. Technical note: Preliminary results with a tannin extract on the performance and mortality of growing rabbits in an enteropathy infected environment. World Rabbit Sci., 2006, vol. 14, pp. 189-192.

5. Mann D. L. Stress activated cytokines and the heart. Ann. Rev. Physiol., 2003, vol. 65, pp. 81-101.

6. Sein O. B., Umerenkov I. A., Trubnikov D. V. Biokhimicheskie i immunologicheskie pokazateli krovi krolikov pri akseleratsionnom metode vyrashchivaniya [Biochemical and immunological parameters of rabbits at acceleration breeding method], Uspekhy sovremennoho estestvoznanyya - Achievements of modern science, 2005, N10, S. 53-53 (In Russian)

7. Wieloch A., Wieczorek D., Staniek H., Szymusiak H., Krejpcio Z., Zieliński R. Tricentric complexes of chromium (III) with glycine and serine ligands. Current Trends in Commodity Science., 2007, pp.1080-1086.

8. Chumachenko V. Yu., Chumachenko V. V., Pavlenko O. A. Rezystentnist' tvaryn i faktory, shcho vplyvayut' na yiyi stan. Doslidzhennya imunnoyi systemy. Faktory, shcho vplyvayut' na rezystentnist' tvaryn, [Resistance of animals and factors affecting its status. The study of the immune system. Factors affecting the resistance of animals]. Veterynarna medytsyna Ukrayiny Veterinary Medicine of Ukraine, 2004, N 4, S. 2629. (in Ukrainian).

9. Bashchenko M. I., Honchar O. F., Shevchenko Ye. A. Krolivnytstvo [The Rabbits Farming] Cherkasy: Cherkaskyy instytut APV, 2011. 302 s. (in Ukrainian).

10. Wang M. Q., Li H., He Y. D., Wang C., Tao W. J., Du Y. J. Efficacy of dietary chromium (III) supplementation on tissue chromium deposition in finishing pigs. Biol Trace Elem Res., 2012, vol. 148, no 3, pp. 316-321.

11. Rao S. V., Raju M. V., Panda A. K., Poonam N. S., Murthy O. K., Sunder G. S. Effect of dietary supplementation of organic chromium on performance, carcass traits, oxidative parameters, and immune responses in commercial broiler chickens. Biol Trace Elem Res., 2012, vol. 147, no 1-3, pp.135-141.

12. Staniek H., Krejpcio Z., Iwanik K., Szymusiak H., Wieczorek D. Evaluation of the Acute Oral Toxicity Class of Trinuclear Chromium (III) Glycinate Complex in Rat. Biol Trace Elem Res., 2011, vol. 143, no 3, pp. 1564-1575.

13. Kravtsiv R. Y., Maslyanko R. P., Kravtsiv Yu. R. Suchasnyy stan vchennya pro fahotsytoz, [Current state of the phagocytosis theory]. Naukovyy visnyk LNAVM im. S. Z. Hzhytskoho - Scientific Messenger of Lviv National University of Veterinary Medicine and Biotechnologies named after S. Z. Gzhytskyj, 2005, T. 7, N 2, Ch. 1., S. 71-77 (in Ukrainian).

14. Kalashnikov A. P. Normy i ratsiony kormleniya selskokhozyaystvennykh zhivotnykh (spravochnoe posobie) [Norms and feeding rations of agricultural animals (handbook)], 2003, M: Ahropromyzdat, 345 s (In Russian)

15. Kosinov M. V., Kaplunenko V. H. Sposib otrymannya karboksylativ metaliv «Nanotekhnolohiya otrymannya karboksylativ metaliv» [Method for metal carboxylates obtaining «Nanotechnology of obtaining metals' carboxylates»], Patent Ukrayiny N 38391, 2009 (in Ukrainian).

16. Vlizlo V. V., Fedoruk R. S., Ratych I. B. Laboratorni metody doslidzhen' u biolohiyi, tvarynnytstvi ta veterynarniy medytsyni: dovidnyk. [Laboratory methods of research in biology, and veterinary medicine: a guide], SPOLOM, 2012, 764 s. (in Ukrainian).

17. Moscati L., Dal Bosco A., Battistacci L., Cardinali R., Mugnai C., Castellini C. Native immunity and oxidative traits of growing rabbits. World Rabbit Sci., 2008, vol. 16, pp. 213-220.

Стаття надійшла до друку 10.06.2013 p. 